\title{
KASVATUS\&AIKA
}

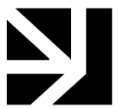

VERTAISARVIOITU

KOLLEGIALT GRANSKAD

PEER-REVIEWED

ArtikKeLI

https://doi.org/10.33350/ka.75134

\section{Historiallisen tiedon luonne ja historian tekstikäytänteet lukiolaisten kuvaamana}

\author{
Anna Veijola, Sari Sulkunen \& Matti Rautiainen
}

\begin{abstract}
Artikkelissa tarkastellaan, millaisia historiallisen tiedon luonteen kuvauksia lukiolaiset tuottivat tutkivan historian oppimisen kurssilla sekä millaiseen tekstitoimintaan nämä kuvaukset kytkeytyivät. Aineistona tutkimuksessamme on 19 lukiolaisen tekstit, jotka on kirjoitettu viikon mittaisen tutkivan oppimisen projektin lopussa. Tutkivan oppimisen viikon pääajatuksena oli vahvistaa opiskelijoiden ymmärrystä historiallisen tiedon rakentumisen tavoista sekä historiallisen tiedon luonteesta. Tekstit on analysoitu teoriaohjautuvalla sisällönanalyysillä. Opiskelijoiden teksteissä ilmeni runsaasti tekstitoiminnan kuvausta. Erilaisten lähdeaineistojen kanssa toimiminen ja johtopäätösten tekeminen niiden pohjalta sai historiallisen tiedon rakentumisen prosessin näkyväksi opiskelijoille. Tekstit osoittavat myös, miten historian sisältöjen ja taitojen oppiminen yhdistyivät tutkivan oppimisen prosessissa. Historiallisen tiedon luonne näyttäytyi tutkimusprosessin jälkeen selkeästi tulkinnallisena. Artikkelissamme raportoidun oppimisprojektin haasteeksi muodostui, että lukiolaisilla ei ollut keinoja arvioida tulkintojen luotettavuutta tai totuudellisuutta.
\end{abstract}

\section{Johdanto}

Suomessa on jo vuosikymmenien ajan pyritty muuttamaan historian opetusta faktoja ja kansallista kertomusta korostavasta opetuksesta opiskelijan omaa aktiivista tulkintaa ja historiatiedon luonnetta tarkastelevan oppimisen suuntaan. Nykyinen lukion historianopetuksen perusta luotiin vuoden 1994 opetussuunnitelmassa. Muutos oli radikaali, sillä perinteisestä, kronologisesta historian opiskelusta siirryttiin temaattiseen, historian formaaleja käsitteitä, kuten muutosta ja jatkuvuutta, korostavaan suuntaan. Muutoksen perustavoitteena oli syventää lukiolaisten käsitystä historiasta. Nykyisissä peruskoulun ja lukion opetussuunnitelmissa historianopetuksen tavoitteena on yhä selkeämmin historiatieteen luonteeseen pohjaavat tiedon hankkimisen, analysoimisen ja tuottamisen taidot. (Opetushallitus 2014; Opetushallitus 2015.) Historian taitojen oppiminen edellyttää historialle tyypillisen tiedon jäsentämisen, kuten syy- ja seuraussuhteiden, muutoksen ja jatkuvuuden sekä aikakäsityksen, hallintaa. Oppijan tulee omaksua historian tekstitaitoja ja kyetä toimimaan monimuotoisen lähdemateriaalin kanssa, analysoimaan sitä, muodostamaan sen pohjalta 
päteviä tulkintoja, sekä pohtimaan menneisyydelle luotuja merkityksiä. (Opetushallitus 2014, 415, ks. myös Seixas \& Ercikan 2015, 2; Wineburg 1991a, 73-78; VanSledright 2010, 114, 265-282.)

Nämä taidot - tai sosiokulttuurisesta näkökulmasta yhteisöllisesti määrittyvät käytänteet (esim. Barton 2007) - ovat olennaisia historian tiedonmuodostuksen kannalta. Nokesin (2013, 24-25; ks. myös Wineburg, 1991a) mukaan historian tiedonmuodostuksessa keskeisiä tekstikäytänteitä ovat lähteiden taustoittaminen (engl. sourcing), kontekstualisointi (engl. contextualizing) sekä vertaaminen ja vahvistaminen (engl. corroboration). Lähteiden taustoittamisessa keskeistä on tunnistaa lähteen laatija, lähteen tarkoitus sekä laadinnan konteksti. Kontekstualisointi tarkoittaa lähteen sijoittamista sen alkuperäiseen historialliseen kontekstiin ja tulkitsemista siitä käsin, sillä historian lähdeaineistot ymmärretään laadituiksi tietyssä historiallisessa tilanteessa tiettyä tarkoitusta varten eikä niitä lueta objektiivisina kuvauksina tapahtumista. Analysoimalla lähteiden sisäistä johdonmukaisuutta, vertaamalla eri lähteitä toisiinsa ja sovittamalla ristiriitaisia lähteitä toisiinsa haetaan vahvistusta omalle tulkinnalle tutkittavasta historian tapahtumasta. Laajemmassa mittakaavassa näiden taitojen opettaminen tähtää historiallisen tiedon luonteen sekä historian sisältötiedon syvälliseen ymmärtämiseen ja myös esimerkiksi kriittiseen lukutaitoon (Nokes, Dole \& Hacker 2007; VanSledright 2002). Opetuksessa voidaan tehdä näkyväksi tiedonmuodostuksen periaatteita ja niihin liittyviä tekstikäytänteitä ja siten tukea oppiaineen oppimista sekä kriittisiä ajattelu- ja tekstitaitoja, joita nykylukiossa pidetään erityisenä haasteena (Lukioselvitys 2017, 23-24, 27).

Historia on tiedonala, jossa kielen avulla sekä välitetään tietoa että osoitetaan historiallista ajattelua (Monte-Sano 2011, 213). Historialle tyypillistä on kerronnallisuus: menneisyydestä rakennetaan niin historian tutkijan kuin erilaisten epävirallisten historiakulttuurin tuotosten kautta kertomusta. Historian oppikirjoissa on menneisyys perinteisesti esitetty ristiriidattomista tapahtumaketjuista rakennetussa kertomusmuodossa (Ahonen 2014). Tämä on tukenut ajatusta siitä, että historian oppiminen on valmiiksi työstetyn tarinan toistamista. Historia ei kuitenkaan kuvaa menneisyyttä sellaisena kuin se on ollut, vaan tietomme menneisyydestä perustuu lähteisiin, jotka ovat aina jonkun henkilön tuottama näkemys jostain tilanteesta tai asiasta. Näitä lähteitä tulkitaan teemojen tai kysymysten kautta, jolloin historiallisen tiedon tulkinnallisuus korostuu. (Esim. Seixas \& Morton 2013; Wineburg 1991a; Goldman et al. 2016.) Olennaista on ymmärtää, etteivät historian tekstit kuvaa neutraaleina faktoina koko menneisyyttämme, vaan niissä nostetaan eri näkökulmista käsin esiin merkityksellisiksi koettuja asioita (esim. Lee 2005; Monte-Sano 2011).

Oppilaiden on todettu ymmärtävän historiallisen tiedon luonteen parhaiten, jos he pääsevät itse aktiivisesti rakentamaan kertomusta menneestä. Tällaista historian oppimista on kehittänyt esimerkiksi Peter Seixas (1999). Hän painottaa historian ajattelutaitoja (historical thinking skills) sekä historiatietoisuuden kehittymistä, jota tarvitaan muun muassa his torialle luotujen merkitysten analysoimiseen ja arvioimiseen. Sam Wineburg (2001) sekä Abby Reisman (2012) puolestaan korostavat historiallista ajattelua (historical thinking), jota voi kehittää dokumenttiaineistoon pohjaavilla oppitunneilla. Oppitunneilla harjoitetaan erilaisia lukustrategioita; ajatuksena on, että näiden lukustrategioiden avulla opiskelija oppii suhtautumaan kriittisesti nykypäivänkin tiedonvälitykseen. Jannet van Drie sekä Carla van Boxtel (2008) puolestaan korostavat historiantutkimukselle tyypillistä historiallista perustelemista (historical reasoning), jossa olennaisia taitoja ovat lähteiden kanssa työskentely sekä argumenttien muodostaminen. Kaikissa näissä malleissa korostuu tutkiva historian oppiminen, johon sisältyy oppijan aktiivinen rooli lähdeaineiston tulkitsijana sekä 
menneisyyttä koskevan kertomuksen rakentajana ja analysoijana (Voet \& de Wever 2016; Voet \& de Wever 2017, 207).

Dokumenttiaineiston kanssa työskentely ei kuitenkaan takaa sitä, että historian oppimisesta tulee oppijaa motivoivaa. Historian taitoja painottavaa ja erityisesti primäärilähteiden analysointiin keskittyvää opetusta on kritisoitu siitä, että pahimmillaan se typistää historian opiskelun lähteiden kanssa puuhailuksi, jolloin oppijalta katoaa kokonaiskuva menneisyydestä ja sille luoduista merkityksistä (esim. Bain 2015, 67; ks. myös Ahonen 2005, 697). Tällöin oppimisesta katoaa helposti myös into ja mielenkiinto. Barton ja Levstik (2004, 232) toteavat, että historian kiinnostavuus löytyy yleensä muualta kuin tiedonalakohtaisten taitojen oppimisesta. He suosittelevat oppijalle merkityksellisiä aiheita, jotka yleensä ovat tunteisiin vetoavia sekä asiaa henkilökohtaistavia teemoja. Tällaisten teemojen kautta oppilaiden kiinnostus herää varmemmin kuin älyllisillä tai kognitiivisilla perusteluilla. Sirkka Ahonen $(2014,65)$ jäsentää vastaavasti asiaa toteamalla, että vaikka historian opiskelu on analyyttista, ei se silti ole "pelkästään intellektuaalista leikkiä menneisyyden arvoituksellisilla jäänteillä", vaan "yhteisön kokemuksen tunnustamista ja työstämistä".

Tutkivan historianoppimisen on nähty olevan hyvä keino kehittää sekä historiaan liittyvää että yleisempää päättelykykyä (Reisman 2012). Tutkivalla oppimisella voidaan kuitenkin tarkoittaa hyvin monenlaista toimintaa. Spronken-Smith ja Walker $(2010,727)$ ovat jaotelleet tutkivan oppimisen kolmeen eri kategoriaan sen mukaan, kuinka strukturoitu oppimisprosessi on. Avoimessa tutkivassa oppimisessa oppijat itse muodostavat tutkimuskysymykset ja myös ohjaavat itseään läpi tutkimusprosessin. Ohjatussa tutkivassa oppimisessa opettaja tarjoaa tutkimuskysymyksen sekä motivoi tutkimukseen, mutta oppijat tutkivat annettua teemaa itseohjautuvasti. Strukturoidussa tutkivassa oppimisessa opettaja sekä tarjoaa tutkittavan aiheen että ohjaa oppijoiden tutkimusprosessia. (Ks. Spronken-Smith \& Walker 2010, 727.)

Tämä artikkeli pohjaa ohjatun tutkivan oppimisen kokeiluun, jossa lukiolaisille annettiin tutkimustehtävä ja siihen liittyvät osatehtävät sekä osa materiaalista valmiina, mutta he saivat itsenäisesti toteuttaa omaa tutkimusprosessiaan. Tällainen usein varsin kompleksisen tieteellisen prosessin pilkkominen rajatumpiin osa-alueisiin on nähty pedagogisesti järkeväksi ratkaisuksi (Pedaste ym. 2015, 48). Tutkimukset ovat myös osoittaneet, että riittävä tuki tutkivan oppimisprojektin aikana kehittää oppijan motivaation lisäksi hänen tiedonrakentamisen ja päättelemisen kykyään sekä hänen kykyään ottaa vastuuta omasta oppimis prosessistaan (Kirschner ym. 2006).

Viime vuosina on tutkittu runsaasti niin historioitsijoiden ja koululaisten tapoja lukea historiallisia tekstejä kuin myös käytänteitä, joilla opettajat voisivat tukea oppilaitaan historiallisten tekstien lukemisessa. Jeffery D. Nokes (2011) on tarkastellut näitä tutkimuksia ja todennut, että historian tekstitaitojen oppimisen haasteena ovat oppilailla olevien historian sisältötietojen niukkuus suhteessa tulkittaviin dokumentteihin ja myös opettajien liian suuret odotukset mitä tulee oppilaiden kognitiivisiin taitoihin kuten esimerkiksi lukutaitoon. Lisäksi haasteena ovat oppilaiden virheelliset käsitykset historiallisen tiedon luonteesta ja historiasta tieteenalana sekä yleisemminkin oppilaiden liian yksinkertaistetut maailmankuvat. Näiden tutkimusten vuoksi päädyimme tarkastelemaan lähemmin sitä, miten opiskelijat kuvaavat historiallisen tiedonmuodostuksen tekstikäytänteitä, sisältötietoa sekä jo tehtävänannonkin mukaista historiallisen tiedon luonnetta.

Tämä artikkeli perustuu viikon mittaiseen tutkivan oppimisen projektiin, jossa oppilaat saivat annetun tutkimuskysymyksen pohjalta melko vapaasti rakentaa omia perusteltuja näkemyksiään suhteessa tutkimustehtävään. Projekti kokonaisuudessaan on kuvattu opettajille suunnatussa oppimateriaalissa (Veijola \& Rautiainen 2018). Projektin keskeisenä tar- 
koituksena oli lisätä lukiolaisten ymmärrystä historiallisen tiedon luonteesta. Lukiolaiset saivatkin itse aktiivisesti rakentaa kertomusta menneestä, jotta he eivät kokisi historian olevan siirrettävää kertomusta menneestä (ks. Nokes 2011). Heillä oli käytössään alkuperäisaineistoa ja tutkimuskirjallisuutta sekä kurssin edetessä myös internetin tarjoamat tiedonhankintamahdollisuudet. Pyrimme rakentamaan sellaisen oppimiskokonaisuuden, jossa ei törmättäisi ongelmiin, joita on raportoitu aikarajan tiukkuuden ja tehtävämateriaalin suppeuden aiheuttavan. Erityisesti dokumenttipohjaisten kynä-paperi -harjoitusten ongelmaksi on nähty, että ne kaventavat vastaajan näkökulmaa: tehtäväorientoituneesti toimiessaan oppija olettaa saavansa tarvittavan tiedon annetuista dokumenteista ja jättää täten dokumenttien ulkopuolisen tietonsa käyttämättä (esim. Reisman 2015, 34-38).

Tämä tutkimuksemme keskeisinä kysymyksinä ovat:

1) Millaisia historiallisen tiedon luonteen kuvauksia tutkiva oppiminen tuotti?

2) Millaiseen tekstitoimintaan opiskelijat kytkivät kuvauksensa?

Artikkeli pohjaa Suomen Akatemian rahoittamaan nelivuotiseen tutkimushankkeeseen Kohti tiedonalakohtaista ajattelua lukiossa: historian tekstitaitojen hallinta, oppiminen ja arviointi. Siinä historiantutkijat ja -kouluttajat sekä kielentutkijat tutkivat yhteistyössä historian tekstitaitojen opettamista ja oppimista.

\section{Tutkimuksen toteuttaminen}

Tutkimuksen aineisto on kerätty osana lukiossa toteutettua tutkivan oppimisen viikkoa, johon osallistui 24 opiskelijaa. Aineistona on 19 opiskelijan kurssin lopuksi kirjoittamat tekstit, joissa he vastasivat tehtävänantoon "Mitä opitte historiallisesta tiedosta viikon aikana?". Kurssille osallistuneista lukiolaisista noin puolet oli ensimmäisen vuosiluokan opiskelijoita ja puolet toisen vuosiluokan. Mukana kurssilla oli myös yksi lukiota kolmatta vuotta opiskeleva. Kurssi järjestettiin viisipäiväisenä maanantaista perjantaihin kestävänä toimintana. Maanantaista torstaihin lukiolaiset työskentelivät yliopistosta tulleiden ohjaajien johdolla kuusi tuntia kunakin päivänä ja perjantaina kahden oppitunnin verran. Kurssille osallistuneilta lukiolaisilta pyydettiin lupa käyttää kurssin kuluessa syntyneitä tuotoksia (esimerkiksi kirjoitelmia, ryhmätyön tuotoksia) tutkimusaineistona, ja he antoivat tähän suostumuksensa. Opiskelijat työskentelivät viikon aikana seitsemässä ryhmässä, joissa kussakin oli kahdesta viiteen henkeä. Tutkimustehtävänä oli selvittää, kuka yritti mahdollisesti murhata presidentti Urho Kekkosen Kultarannassa juhannuksena 1957. Tätä varten opiskelijoille oli tuotu tutkimuskirjallisuutta sekä runsaasti erilaisia arkistolähteitä muun muassa Urho Kekkosen arkistosta.

Kurssin ensimmäisenä päivänä opiskelijat orientoituivat teemaan kirjoittamalla, mitä historia on ja miksi sitä heidän mielestään opiskellaan koulussa. Tämän jälkeen aloitettiin varsinainen tutkimustyö perehtymällä ensin kahteen lähteeseen sekä lähteen luotettavuuden arviointiin. Lisäksi taustoitettiin lyhyesti tulevan tutkimuksen kontekstia. Varsinainen tutkivan oppimisen työskentely tapahtui pienryhmissä, joissa opiskelijat itsenäisesti perehtyivät aluksi laajaan arkistomateriaaliin sekä kirjallisuuteen ja muodostivat tämän perusteella näkemyksensä siitä, kuka tai ketkä olivat Urho Kekkosen mahdollisen murhayrityksen takana ja miksi murhayritys tapahtui. Opiskelijoiden palautettua keskiviikkona pienryhmiensä väliraportit he saivat käyttää vapaasti myös internetiä ja syventää sieltä löytyvän informaation avulla pienryhmänsä tutkimusprosessia. Väliraportit esitettiin yhteisesti koko 
ryhmälle. Lisäksi pienryhmät laativat lopputyönään uutislähetysvideot, jotka koko ryhmä katsoi yhdessä.

Kurssin viimeisenä päivänä opiskelijoiden kanssa katsottiin vielä yhden pienryhmän uutislähetys uudelleen ja pohdittiin tämän pohjalta, millainen uutisen taustalla ollut tutkimusprosessi oli ollut ja miten siinä näkyi historialle tyypillinen tapa rakentaa tietoa. Tässä vaiheessa ohjaajat lisäsivät käsittelyyn myös muutaman opiskelijoillekin jaetun alkuperäislähteen (muun muassa Sensaatio Uutiset). Näin yhdessä analysoimisen avulla syvennettiin ymmärrystä historiallisen tiedon rakentumisprosessista. Näiden lähteiden sekä opiskelijoiden esille nostamien huomioiden kautta käytiin läpi historiallisen tiedon rakentumisen eri osa-alueita sekä historiantutkijan tutkimusprosessia. Tutkivan oppimisen viikon viimeisenä työnä opiskelijat kirjoittivat jokainen oman tekstinsä siitä, mitä he olivat oppineet historiallisesta tiedosta kuluneen viikon aikana.

Tutkivassa oppimisessa keskeistä on tutkimuksen teon lisäksi oman toiminnan reflektointi sekä kommunikointi muiden toimijoiden kanssa. Jokaisen päivän päätteeksi opiskelijoita pyydettiinkin miettimään omissa pienryhmissään, mikä oli tutkimuksen kannalta päivän tärkein löytö (oivallus) ja miten se syntyi. Lisäksi heitä pyydettiin pohtimaan, mikä päivässä oli vaikeinta ja miten he ratkaisivat ongelman. Opiskelijat myös kirjoittivat omat tuotoksensa siitä, mikä oli heidän oma osuutensa pienryhmänsä työskentelyssä ja miten he kokivat päivän työskentelyn. Kurssin kuluessa pyrimmekin tukemaan opiskelijoita myös reflektoimaan omaa ja oman pienryhmänsä toimintaa nimenomaan tutkimuksen teon ja yhdessä toimimisen näkökulmista käsin.

\section{Aineiston analyysi}

Aineiston analyysi ja luokittelu on toteutettu aineistolähtöisesti tarkastelemalla, millaisia teemoja nousi esiin opiskelijoiden kirjoittamista teksteistä kurssin lopussa, kun tehtävänantona oli: "Kirjoittakaa kirjoitelma aiheesta Mitä opitte historiallisesta tiedosta viikon aika$n a$ ?" Aineiston analyysissa on hyödynnetty tutkijatriangulaatiota (ks. Laine ym. 2007) siten, että aineiston ovat analysoineet sekä historian pedagogiikan että kielitieteen tutkijat. Tutkijat kävivät aluksi aineiston itsenäisesti läpi huomioiden ja ryhmitellen opiskelijoiden teksteistä merkityksellisiksi katsomiaan seikkoja. Tutkijat päätyivät itsenäisesti muodostamaan samat kategoriat kuin analyysissa esitetään, joskin käyttäen aluksi kukin omalle tieteenalalleen tyypillistä käsitteistöä. Esimerkiksi historian pedagogiikan tutkija ja kielitieteen tutkija sijoittivat samat sisällöt yläkategoriaan Tiedonmuodostuksen tekstikäytänteet, mutta historian pedagogiikan tutkija nimesi tämän opetussuunnitelmassakin (Opetushallitus 2014, 415) olevalla historian tekstitaitojen määritelmällä Tiedon hankkiminen, tulkitseminen ja omien johtopäätösten tekeminen, kun taas kielitieteilijä nimitti ryhmää Tiedonmuodostuksen tekstikäytänteiksi. Yhteisten yläkategorioiden tarkistamisen ja niiden nimeämisen jälkeen yksi tutkijoista kävi vielä kerran koko aineiston läpi.

Aineistolähtöisyydestä huolimatta analyysia on ohjannut teoria- ja tutkimuskirjallisuuden pohjalta rakentunut tieto. Analyysi onkin toteutettu teoriaohjaavan sisällönanalyysin avulla. (Ks. Tuomi \& Sarajärvi 2009, 117-120.) Tehtyyn ryhmittelyyn ovat vaikuttaneet tutkimukset, joissa historian tekstitaitojen kannalta keskeisiksi on nähty historiallisen tiedon hankkimiseen ja erityisesti sen tulkintaan liittyvät toimintatavat (esim. Wineburg 1991ab). Näissä keskeistä on esimerkiksi historiallisen tiedon kontekstualisointi, kirjoittajan intentioiden pohdinta sekä sisältötiedon hallinta ja käyttö (esim. VanSledright 2002; Van Drie \& Van Boxtel 2008; Rantala \& van den Berg 2013; Rantala ym. 2016; Rantala \& 
Veijola 2016) sekä laajemmin oppijoiden tapa hahmottaa historiallisen tiedon luonnetta (esim. Nokes 2011).

Teksteissään opiskelijat kirjoittivat historiallisen tiedon oppimisen lisäksi tutkivan oppimisen viikon herättämistä ajatuksista myös laajemmin. He kirjoittivat esimerkiksi siitä, miten tutkiminen vaatii tekijältään sinnikkyyttä ja kestävyyttä sekä välillä myös tylsyyden sietämistä. Rajasimme nämä teemat pois tästä artikkelista ja keskitymme tarkastelemaan historiallisen tiedon luonteen sekä historian tekstikäytänteiden kannalta olennaisia piirteitä.

\section{Tulokset}

Ryhmittelimme opiskelijoiden teksteistä nousseet teemat kolmeen kategoriaan (ks. taulukko 1):

1) Tiedonmuodostuksen tekstikäytänteisiin liittyvät kuvaukset

2) Sisältötietoon liittyvät maininnat

3) Historiallisen tiedon luonteeseen liittyvät kuvaukset

\begin{tabular}{|c|c|c|}
\hline $\begin{array}{l}\text { Opiskelijoiden teksteissä } \\
\text { olevat teemat }\end{array}$ & $\begin{array}{l}\text { Asiasta kirjoittanei- } \\
\text { den opiskelijoiden } \\
\text { lukumäärä }(\mathrm{N}=19)\end{array}$ & $\begin{array}{l}\text { Opiskelijoiden vastauksista esiin nousseita, } \\
\text { tähän kategoriaan luokiteltuja asioita }\end{array}$ \\
\hline $\begin{array}{l}\text { Tiedonmuodostuksen } \\
\text { tekstikäytänteisiin (tiedon } \\
\text { hankkimiseen, analysoi- } \\
\text { miseen sekä omien johto- } \\
\text { päätösten tekemiseen) } \\
\text { liittyvät kuvaukset }\end{array}$ & 15 & $\begin{array}{l}\text { - Lähdetyöskentelyyn liittyvien tekstikäytäntei- } \\
\text { den kuvaus: lähteiden taustoittaminen, } \\
\text { kontekstualisointi, vertaaminen ja tulkinnan } \\
\text { vahvistaminen } \\
\text { - Lähteen lukemiseen liittyvät seikat: tiedon } \\
\text { paljous ja saatavuus, tiedonhaun helppous tai } \\
\text { haastavuus, lukemisen tarkkuus, olennaisen } \\
\text { erottaminen, lähteiden moninaisuus, lukemi- } \\
\text { sen tekstilajikohtaiset haasteet } \\
\text { - Tulkinnan kriittinen tarkastelu } \\
\text { - Tiedonmuodostuksen yhteisöllinen ulottuvuus: } \\
\text { kritiikki, ryhmän näkökulmat } \\
\text { - Tutkimustiedon riippuvuus lähdeaineiston } \\
\text { saatavuudesta: joistain asioista on niukalti tai } \\
\text { ei lainkaan tietoa, joistain taas niin paljon, että } \\
\text { sen käsittely on haastavaa. }\end{array}$ \\
\hline $\begin{array}{l}\text { Sisältötietoon liittyvät } \\
\text { maininnat }\end{array}$ & 5 & $\begin{array}{l}\text { - Kokonaiskuvan ja laajempien yhteyksien } \\
\text { luominen; tiedon käsittelyn hankaluus, jos ei } \\
\text { tunne kontekstia } \\
\text { - Aiheesta uuden oppiminen } \\
\text { - Yhteyksien löytämisen tärkeys }\end{array}$ \\
\hline $\begin{array}{l}\text { Historiallisen tiedon } \\
\text { luonteeseen (tulkinnalli- } \\
\text { suus, luotettavuuden } \\
\text { arviointi) liittyvät } \\
\text { kuvaukset }\end{array}$ & 8 & $\begin{array}{l}\text { - Tiedon totuudellisuus (oikea tieto) } \\
\text { - Tiedon tulkinnallisuus: lähteiden subjektiivi- } \\
\text { suus ja näkökulmaisuus, } \\
\text { olemassa olevaa tietoa tulkitaan eri tavoin } \\
\text { (monitulkintaisuus) } \\
\text { - Tutkijan ja lukijan roolien korostuminen } \\
\text { tiedon varmistamisessa }\end{array}$ \\
\hline
\end{tabular}

Taulukko 1: Opiskelijoiden teksteissä esiin nousseet seikat, joihin historiallisen tiedon oppiminen kiinnittyi $(N=19)$.

\section{Tiedonmuodostuksen tekstikäytänteet}

Kuvatessaan historiallisesta tiedosta oppimaansa opiskelijat kuvasivat runsaasti tiedonmuodostuksen tekstikäytänteitä (ks. taulukko 1). Osa opiskelijoista kytki kuvauksensa tutki- 
musprosessiin kokonaisuudessaan, osa puolestaan lähdetyöskentelyssä huomioitaviin seikkoihin. Seuraavassa katkelmassa näitä moninaisia tekstikäytänteiden kuvauksia on korostettu lihavoinnilla:

\section{[V]anhaa tietoa saattaa olla aika vaikea tulkita vanhan kirjoitustyylin vuok- si. Aineistoja tutkiessa pitää ottaa huomioon niiden lähteet, kuka ne on kir- joittanut, missä, milloin ja miksi. Pitää myös osata ajatella avarasti, eikä vain tarttua heti ensimmäiseen mahdolliseen teoriaan. Ensin olisi hyvä myös pystyä kasaamaan aineistot yhteen ja keräämään niistä vasta sitten tär- keämmät yksityiskohdat, joiden pohjalta lähteä rakentamaan teoriaa siitä, mitä on mahdollisesti voinut tapahtua. Pitää myös kiinnittää huomiota siihen, millä ajalla/aikakaudella tutkittava asia on tapahtunut. Millaista politiikka, ihmisoikeudet ja yhteiskuntajärjestelmä yms. ylipäätään oli tuolloin. On myös tärkeää kirjata kaikki hyvin ylös esim. ajatuskarttojen avulla. (Opiske- lija 1.)}

Opiskelija kirjoittaa aluksi lähteen lukemiseen liittyvästä seikasta, eli vanhasta kirjoitustyylistä, joka hankaloittaa tiedon hankintaa. Tämän jälkeen hän nostaa esiin lähdetyöskentelyyn liittyvistä tekstikäytänteistä lähteiden taustoittamisen ja erikseen siihen liittyvän kontekstualisoinnin. Kontekstualisointi näkyy opiskelijan vastauksessa oikeastaan kahdessa eri merkityksessä: katkelman alussa hän kirjoittaa analysoitavan lähteen kontekstualisoinnista, katkelman loppupuolella yleisesti historiallisen kontekstin luomisesta. Tekstissä on esillä myös tiedon analysoimisen ja tuottamisen prosessiin liittyviä tekstikäytänteitä. Opiskelija esittää, miten aineistoista tulee kirjata tietoa esimerkiksi ajatuskarttojen avulla, etsiä niistä yksityiskohtia ja rakentaa aineistopohjaisesti teoriaa tapahtuneesta. Kyseinen katkelma osoittaakin, miten historian tekstikäytänteissä lähdetyöskentely, historiallisen kontekstin luominen sekä tutkimusprosessi kietoutuvat yhteen.

Useat opiskelijat nostivat vastauksissaan esiin, että aineistoa tulkittaessa tulee ottaa huomioon konteksti, kirjoittaja, ajoitus sekä asiasisältö. Opiskelijat eivät kuitenkaan kytkeneet näitä mainintoja tekemäänsä tutkimukseen tai analysoimiinsa lähteisiin, joten ne jäivät varsin yleiselle tasolle. Opiskelijoiden tekstien pohjalta ei voikaan todeta, kuinka syvällisesti he hahmottivat, miksi kyseiset asiat ovat olennaisia historiallisen tiedon muodostuksen kannalta. Opiskelijat kuitenkin huomioivat teksteissään sen, että historia on tulkinnallista. Tietoa muodostettaessa tarvitaan niin lähteiden tulkintataitoja - mukaan lukien tiedon luotettavuuden pohdinnan puntaroimista - kuin kykyä hahmottaa aikakauden tilanteita:

Tietoon ja sen laajuuteen vaikuttivat lähde, kirjoittaja, asiayhteys, ajoitus... Luotettavuuteen vaikuttavat monet asiat ja niiden taustat. Riippuen tiedonlähteen kannasta tiedon laatu voi vaihdella suuresti ja mikäli aiheeseen liittymättömiä esim. kirjeitä yhdistetään valmiiksi monimutkaiseen asiayhteyteen, voi lopputulos olla todella sekava ja todellisuudesta poikkeava. Historiallisen tiedon käsittely voi olla todella hankalaa, mikäli ei ole valmiiksi itsellä olemassa tietoa siihen, tiedon aikakauden tai esim. tietoon liittyvistä ihmisistä. (Opiskelija 10.)

Yllä olevassa katkelmassa on myös kiinnostava huomio siitä, miten historiallisen tiedon tulkinnallisuus ei tarkoita, että lähteitä voisi käyttää miten vain, vaan tulkinnan tulee olla todenperäistä. Kuten opiskelijakin tekstissään hahmottelee, todenperäisyys vahvistetaan historiatieteelle tyypillisillä tekstikäytänteillä, esimerkiksi kontekstualisoimalla sekä lähteet että tapahtuma. Tätä varten tulkitsija tarvitsee myös sisältötietoa käsiteltävästä asiasta. 
Tiedonmuodostuksen yhteisöllisen ulottuvuuden kuvausta oli muutamien opiskelijoiden teksteissä. Näille, kuten teksteissä esiintyneille tutkimusprosessin kuvauksillekin, oli tyypillistä yleiselle tasolle jääminen:

Opin myös, että omaa ajattelua ja päätelmiä pitää pystyä ajattelemaan myös kriittisesti. Voi esim. miettiä onko omassa tulkinnassa joitakin aukkoja, jotka lopulta kumoavat oman päätelmän. Huomasin myös että keskustelu oman ryhmän kanssa on tärkeää, sillä mitä useampia mielipiteitä ja näkemyksiä tulee esiin, sen parempi. (Opiskelija 1.)

Kuvauksissa toistuu ajatus aktiivisesta tiedon rakentamisen prosessista. Työskennellessään erilaisten lähteiden kanssa opiskelijat kokivat oppivansa lukemisen ja oppimisen ydintaitoja: "Aineiston pyörittelemisen aikana oppi myös hahmottamaan tärkeimmät asiat tekstistä, sekä yhdistämään ne laajempiin kokemuksiin." (Opiskelija 21.)

Opiskelijat nostivat esiin tutkimustiedon riippuvuuden lähdeaineiston saatavuudesta. $\mathrm{He}$ kuvasivat, kuinka joistain asioista on niukalti tai ei lainkaan tietoa, joistain taas niin paljon, että sen käsittely on haastavaa. Kurssin alussa opiskelijoille jaettiin sekä määrällisesti että laadullisesti varsin runsas dokumenttiaineisto, ja yksi opiskelija toteaakin tekstissään oppineensa kurssin myötä, että historiaa tutkittaessa täytyy analysoida ja käydä läpi paljon sellaistakin materiaalia, joka ei liity itse tutkittavaan teemaan. Muutama opiskelija toi esiin myös, kuinka tiedon hakeminen käsinkirjoitetuista kirjeistä ja muusta arkistomateriaalista oli haastavampaa kuin tiedon etsintä internetin hakupalveluista. Seuraava katkelma osoittaa myös lähteiden tekstilajikohtaisten haasteiden huomioimisen, vaikkakin melko pinnallisella tasolla:

\section{Historiallisesta tiedosta opin sen että sitä on yllättävän helppo etsiä netistä verrattuna esim. vanhoihin muistioihin tai kirjoitelmiin. Netissä pystyy lait- tamaan hakusanan ja tulos tulee melkein heti ruudulle mutta kirjoitelmissa sitä pitää oikeasti etsiä ja lukea ja se on paljon työläämpää. Itse opin viikon aikana tulkitsemaan paremmin kirjoitelmia ja muita vanhoja muistioita. (Opiskelija 12.)}

Opiskelijoiden tekstit heijastelevat kurssin työskentelytapoja. Koska lähestymistapanamme oli ohjattu tutkiva oppiminen, vaikuttivat tekemämme tehtävänannolliset ratkaisut opiskelijoiden työskentelyyn. Jotta opiskelijat olisivat aluksi tutustuneet alkuperäislähteisiin, päädyimme pyytämään, että he muodostaisivat ensimmäiset tulkintansa alkuperäisaineiston sekä tuomiemme noin 30 tutkimuskirjan perusteella ja vasta tämän jälkeen käyttäisivät tiedonhankinnassa apunaan myös internetiä. Työskentely haastavien käsialojen ja erilaisten dokumenttien kanssa teki opiskelijoille näkyväksi sen, että historiallinen tieto ei ole valmiina olemassa, vaan se on aina jonkun henkilön kokoamaa jonkin aineiston pohjalta.

\section{Sisältötietoon liittyvät maininnat}

Suomalaisilla lukiolaisilla on todettu olevan ongelmia kirjoittajan intentioiden pohdinnassa (esim. Rantala \& van den Berg 2013) sekä lähteiden kontekstualisoinnissa (esim. Kouki \& Virta 2015; Rantala \& Veijola 2016; Veijola 2017). Etenkin kontekstualisoinnin ongelmat kielivät siitä, ettei opiskelijoilla ole ollut joko tarvittavaa sisältötietoa tai kykyä yhdistää historian sisältötietoa tulkintaprosessiinsa. Myös tutkivan oppimisen viikon teksteissä sisältötietoon liittyvät maininnat kytkeytyivät osaksi tutkimusprosessia ja lähteiden kanssa työskentelyä. Sisältötieto liittyi keskeisesti kokonaiskuvan ja laajempien yhteyksien luomiseen, ja sen puute nähtiin tutkimusprosessia hankaloittavana asiana: "Historiallisen tiedon käsit- 
tely voi olla todella hankalaa, mikäli ei ole valmiiksi itsellä olemassa tietoa siihen, tiedon aikakauden tai esim. tietoon liittyvistä ihmisistä." (Opiskelija 8.) Sisältötietoa tarvitaan, jotta "yhteydet löytyisivät paremmin" ja historiantutkijan pitääkin "osata hahmottaa kokonaisuus".

Sisältötieto yhdistyikin opiskelijoiden teksteissä historiallisen kontekstin luomiseen, asioiden välisten yhteyksien löytymiseen ja tätä kautta historian ymmärtämiseen:

Kuten myös ryhmältä kysyttäessä sanoin ääneen, opin katselemaan historiallisia tietoja laajemmissa asiayhteyksissä ja kokonaisuuksissa. Se on mielestäni tärkein oppimani asia, sillä näin voin yhdistää eri tapahtumia toisiinsa ja näin taasen ymmärtää historiaa paremmin kuin aiemmin. (Opiskelija 6.)

Opiskelijan tekstissä nousee esiin tiedonmuodostuksen ja sen tekstikäytänteiden sekä sisältötiedon tiivis suhde, josta myös tutkijat ovat kirjoittaneet (mm. Fang \& Coatoam 2013; Morton \& Seixas 2013). Sisältötiedon esiin nouseminen osoittaa, että taito-oppimisen ohella historiassa tarvitaan myös sisältötieto-oppimista.

Historian kouluopetuksen on perinteisesti nähty kannustavan vuosilukujen, nimien ja tapahtumien oppimiseen ulkoa (Virta 2002, 38-39). Historianopetus on tällöin painottunut menneisyydestä luodun kertomuksen toistamiseen. Tällaisessa oppimisessa sisältötiedolla on hyvin itsenäinen rooli. Tutkivassa oppimisessa sisältötietojen etsiminen ja kartuttaminen kytkeytyvät osaksi tehtävää tutkimusta. Opiskelijoiden tekstien vähäinen sisältötietoon kiinnittyminen saattaa kertoa siitä, että tutkivan oppimisen viikon aikana sisältötiedon hankkiminen tai osaaminen ei jäänyt erilliseksi toiminnaksi, vaan kytkeytyi luontevaksi osaksi tutkivaa prosessia, jolloin valtaosa opiskelijoista ei katsonut tarpeelliseksi korostaa sisältötiedon oppimista. Toki voi myös olla, etteivät opiskelijat itse pohtineet, millaista tietoa he tutkimusprosessin aikana tarvitsivat ja miten sitä käsittelivät. Ainoastaan yksi opiskelija mainitsi oppineensa työskentelyn myötä tietystä aiheesta: Kekkosesta.

\section{Historiallisen tiedon luonteen kuvaukset}

Tehtävänannon mukaisesti opiskelijat toivat teksteissään esiin, mitä he olivat oppineet viikon kuluessa historiallisen tiedosta. Useimmat opiskelijoista sitoivat kuvauksensa historiallisesta tiedosta juuri toteuttamaansa tutkimusprosessiin. Kuvaukset kytkeytyivät yhtäältä tiedon luotettavuuteen ja toisaalta tiedon tulkinnallisuuteen, ja opiskelijoiden vastauksissa nämä linkittyivät toisiinsa:

\section{Tällä viikolla historiallisesta tiedosta opin sen, että sitä on saatavilla monis- ta eri lähteistä ja kaikki lähteet eivät ole yhtä luotettavia. Myös tieto samas- ta asiasta voi vaihdella rïppuen sïtä kuka sen on kirjoittanut ja mitä tai ketä varten se on julkaistu. Täytyy osata katsoa asioita laajasti ja ymmärtää asiayhteys. Historiallista tietoa katsellessa täytyy myös kiinnittää huomiota siihen kuka sen on kirjoittanut. (Opiskelija 18.)}

Oheisessa katkelmassa historiallisen tiedon tulkinnallisuus näyttäytyy siinä, että samasta asiasta voi olla eri näkemyksiä. Opiskelija antaa esimerkkejä siitä, miten tiedon luotettavuutta voidaan arvioida. Hän mainitsee, että tulee kiinnittää huomiota tekstin laatijaan sekä tilanteeseen, jossa teksti on laadittu. Lisäksi historiallisen kontekstin tunteminen parantaa luotettavuuden arvioimisen mahdollisuutta. 
Todenperäisyyttä voi lähteä selvittämään monelta kantilta mm. milloin aineisto on kirjoitettu, kenen toimesta, kenellä ja mistä syystä. On myös tärkeää tarkistaa missä historiallinen tieto on julkaistu. Aineiston kirjoitusajankohta voi vaikuttaa siihen, miksi aineisto on luotu ja aineiston tarkastelussa tulee miettiä myös mitä muualla maassa on tapahtunut ja voivatko muut tapahtumat vaikuttaa siihen miksi tämä aineisto on luotu. (Opiskelija 7.)

Opiskelijat korostivat sitä, että tulkitsijan täytyy tiedostaa lähteiden luotettavuuteen liittyviä seikkoja:

Historiallinen tieto on vanhaa, ja usein siihen liittyvät henkilöt tai heidän läheiset eivät ole itse kommentoimassa tai kertomassa asioiden muita näkökulmia, joten tieto on hieman vajavaista ja usein vain muutaman ihmisen näkemys tapahtuneesta. Tieto ei myöskään ole aina luotettavaa, varsinkaan jos se kerrotaan vasta vuosia myöhemmin tapahtuneesta; ihmismieli unohtaa ja saattaa muokata tietoa kun sitä ei käytä. Aistihavainnot eivät myöskään aina ole luotettavia tiedonlähteitä. Kirjoitettua tietoakin voi kopioida ja muokata sekä levittää otettuna pois alkuperäisestä kontekstista. (Opiskelija 10.)

Kuten ylläolevastakin tekstikatkelmasta on nähtävissä, opiskelijat luettelivat pätevästi niitä seikkoja, joita historiallisen lähteen kanssa toimiessa tulee ottaa huomioon. He pohtivat myös, miksi samastakin tapahtumasta on olemassa erilaisia näkemyksiä, ja tätä kautta hahmottivat, kuinka historiallinen tieto on tulkinnallista. Opiskelijoiden tekstit paljastavat kuitenkin, että opiskelijoilla oli vaikeuksia hahmottaa, miten eri vaihtoehtojen ja mahdollisesti ristiriitaisenkin tiedon kanssa olisi tullut toimia. Esimerkiksi yksi opiskelijoista kirjoittaa, kuinka: "Historia on näkökulmien tiede ja se vaatii kaikkien näkökulmien tutkintaa ja usein versioita syntyy useampi, joista on vain valittava todennäköisempi." (Opiskelija 20.) Tällainen näkemys heijastaa historiallisen tiedon totuudellisuutta ja on ongelmallinen, sillä sen sijaan, että kuvattaisiin sitä, miksi eri henkilöt ovat nähneet menneisyyden tapahtumat eri tavoin, päädytään korostamaan yhtä vaihtoehdoista ja pahimmassa tapauksessa jätetään muut mainitsematta. Wineburg (1991b) on tutkimuksessaan kuvannut, kuinka historian "noviiseille" on tyypillistä, että ristiriitaista informaatiota havaitessaan he pyrkivät pääsemään eroon ristiriidasta häivyttämällä sitä.

Historian moniäänisyys ja -tulkintaisuus näkyi opiskelijoiden teksteissä siinä, että he totesivat lähdeaineiston antavan mahdollisuuksia erilaisiin tulkintoihin. Sen sijaan, että he olisivat todenneet, ettei lähdeaineiston pohjalta voi todeta mitään yksiselitteistä tai varmaa vaan voi ainoastaan esittää erilaisia perusteltuja vaihtoehtoja, heistä osa päätyi valitsemaan vaihtoehdoista yhden ja muodostamaan sille aukottomalta tuntuvan selityksen. Syy tälle voi löytyä kurssin työmuodoista. Opiskelijoita pyydettiin suunnittelemaan, toteuttamaan ja videoimaan uutislähetys siitä, kuka yritti murhata Kekkosen Kultarannassa kesällä 1957. Vaikka tehtävänanto ei rajannutkaan pois mahdollisuutta monitulkintaiseen lopputulokseen, saattoi se ohjata opiskelijoita valitsemaan eri vaihtoehdoista yhden ja perustelemaan tämän valintansa. Ongelmaksi näyttäisi jääneen, ettei opiskelijoilla ollut vielä riittävästi välineitä arvioida historiallisen tiedon luotettavuutta ja tulkinnallisuutta. Kurssi kuitenkin avarsi heille ajatusta siitä, ettei historiallinen tieto ole tulkitsijastaan riippumatonta. Näkemys historiallisen tiedon luonteesta heijastelee laajemminkin näkemystä siitä, miten tietoa voidaan saada ja mitä pohjimmiltaan on olemassa. Jos opiskelijalla on sellainen mielikuva, että tieto 
on jo valmiina ja tulkitsijasta riippumatonta, jää opiskelija etsimään "oikeaa vastausta". Jos hän sen sijaan näkee tiedon tulkitsijasta riippuvaisena, on hänen tutkimuksensa lopputuloskin enemmän eri vaihtoehtoja esittelevä, ellei sitten löydy lähdettä, joka vahvistaisi riittävän varmasti jonkin tietyn tiedon.

\section{Pohdinta}

Lukiolaisille järjestetyn tutkivan oppimisen viikon pääajatuksena oli vahvistaa opiskelijoiden ymmärrystä historiallisen tiedon rakentumisen tavoista sekä historiallisen tiedon luonteesta. Opiskelijat rakensivat itse kertomusta menneestä moninaisen lähdeaineiston pohjalta ja tätä kautta saivat kokemusta sekä historiallisen tiedon rakentamisesta että erilaisten tekstien kanssa toimimisesta. Ymmärrys historiallisen tiedon rakentumistavoista ja moninaiset lähteiden kanssa toimimisen taidot ovat keskeisiä paitsi kriittisen ajattelun, myös yksilön historiatietoisuuden kannalta. Historiallisen ajattelun taitoja kehittämällä vahvistetaan myös yksilön historiallista identiteettiä sekä historiatietoisuutta (esim. Thorp 2014, 20-31; Duquette 2015).

Laajan tekstiaineiston kanssa toimiminen ja omien johtopäätösten tekeminen sen pohjalta sai opiskelijoille näkyväksi, miten historiallinen tieto rakentuu. He kuvasivat teksteissään oppineensa sekä yleisiä tutkimukseen tarvittavia taitoja että yksittäisten lähteiden lukemisessa tarvittavia taitoja. Opiskelijat tekivät osuvia huomioita siitä, kuinka tutkimustieto riippuu lähdeaineiston saatavuudesta ja kuinka tärkeää on tuntea tutkittavan asian kontekstia. Nämä huomiot osoittavat, että omakohtainen tutkimusprosessi herätti havaitsemaan seikkoja, joita oppikirjaa lukemalla tuskin olisi hahmottanut. Tällaisia ovat esimerkiksi tiedonmuodostuksen tekstikäytänteet eli lähteiden taustoittaminen, kontekstualisointi, vertaaminen sekä tulkinnan vahvistaminen (Nokes 2011). Ryhmässä toteutetussa tutkivassa oppimisessa näyttäytyi myös tiedonmuodostuksen yhteisöllinen ulottuvuus (Ford \& Forman 2006), sillä tehdyt tulkinnat esitettiin koko ryhmälle ja altistettiin muiden kritiikille. Opiskelijoiden tekstityön kuvaukset osoittivatkin sen, että tutkiva oppiminen tuki historiallisen tiedon tulkinnallisen luonteen oppimista.

Sisältötietojen ja taitojen välinen suhde historianopetuksessa on herättänyt keskustelua. Vaikuttaa siltä, että ainakin osa opettajista painottaa sisältöjen opettamista taitojen kustannuksella (Rantala 2012). Yhtenä perusteluna tälle toiminnalle on, ettei ilman sisältöjen osaamista voi tehdä tulkintaa. Myös Nokes (2011) on todennut, että historian tekstitaitojen oppimisen yhtenä haasteena on opiskelijoiden liian niukat sisältötiedot suhteessa tulkittaviin dokumentteihin. Tutkivassa oppimisessa historian sisältöjen ja taitojen oppiminen yhdistyvät. Tämä näkyi myös opiskelijoiden teksteistä, joissa sisältötiedon merkitys ilmeni toteutetun tutkimusprosessin osana. Opiskelijat itse totesivat, etteivät pystyneet ilman riittävää tietoa esimerkiksi aikakaudesta, henkilöistä tai tapahtumista analysoimaan lähteitä tai tekemään päteviä tulkintoja. Tutkivan oppimisen kurssin aikaresurssien runsaus mahdollisti sen, että opiskelijat pystyivät hankkimaan tarvitsemansa sisältötiedon kirjallisuuden avulla.

Historian oppimisen yhtenä haasteena on nähty opiskelijoiden virheelliset käsitykset historiallisen tiedon luonteesta ja historiasta tieteenalana (Nokes 2011). Tutkivan oppimisen on yleisesti nähty vahvistavan tiedonmuodostuksen perusteiden sekä sisältötiedon oppimista (Moje 2015). Opiskelijoiden teksteissä historiallisen tiedon luonne näyttäytyi oman tutkimusprosessin jälkeen selkeästi tulkinnallisena, joskin haasteeksi muodostui eri versioiden oikeellisuuden ja totuudellisuuden arviointi. Yhtäältä opiskelijat hahmottivat, että lähdemateriaali oli monitulkintaista, toisaalta he näkivät myös sen, että heidän tekemänsä johtopäätökset olivat tulkintoja suhteessa annettuun tehtävään. Historiallisen tiedon tulkinnal- 
linen luonne näyttääkin avautuneen opiskelijoille. Sen sijaan ongelmallisemmaksi muodostui se, miten tehtyjen tulkintojen luotettavuutta tai totuudellisuutta voisi arvioida. Osalla opiskelijoista teksteistä välittyy kuva historiasta tieteenä, jossa tiedon totuus on täysin riippuvaista lähdeaineiston määrästä tai tutkijan tekemistä valinnoista. Opiskelijoiden tekstien pohjalta vaikuttaakin kuin kurssilla olisi ollut hyvä kiinnittää enemmän huomiota siihen, kuinka historiassa merkittävä tulos voi olla myös, ettei lähdeaineiston pohjalta pysty muo dostamaan varmaa päätelmää.

Siitä, onko avoin vai ohjattu tutkiva oppiminen tehokkainta, on erilaisia näkemyksiä (Spronken-Smith \& Walker 2010; vrt. Kirschner ym. 2006). Koska opiskelijaryhmä ei ollut meille ennalta tuttu, päädyimme ohjaamaan tutkimusprosessia antamalla yhteisen tutkimuskysymyksen, tuomalla tutkimusaineistoa mukanamme sekä määrittelemällä väliraportin ja lopputuotoksen muodon. Nostimme myös viikon aikana koko ryhmän yhteiseen keskusteluun havaintoja muun muassa lähteiden luotettavuuden arvioinnista. Lisäksi pyysimme opiskelijoita pohtimaan työnsä etenemistä ja ryhmäprosessia päivittäin kerätyillä palautelomakkeilla. Näyttäisi siltä, että tällä tavoin ohjattuna tutkivan oppimisen prosessi oli opiskelijoita motivoivaa: "Kun pääsee itse tutkimaan ja etsimään tietoa, tuntuu historiallinen tieto paljon mielenkiintoisemmalta." (Opiskelija 16.) Historiallisen tiedon luonteen oppimisen kannalta olisi kuitenkin ollut hyvä kiinnittää vielä enemmän huomiota historiallisen tiedon luotettavuuden arviointiin.

Kesällä 2018 eduskunnassa hyväksyttiin uusi lukiolaki. Sen myötä lukio-opinnoissa vahvistuu oppiainerajat ylittävä oppiminen sekä yhteistyö korkeakoulujen kanssa. Opetussuunnitelmien uudistumisen myötä oppiaineiden tavoitteet suunnitellaan ja kirjoitetaan uudelleen. Artikkelimme lopuksi pohdimme, mitä opetuskokeilumme tulokset tarkoittavat lukiokoulutuksen kehittämisen näkökulmasta.

Jo vuosien 1994, 2003 sekä 2015 historian opetussuunnitelmien perustavoitteena on ollut syventää lukiolaisten käsitystä historiallisen tiedon luonteesta. Oppijasta ei kuitenkaan näiden opetussuunnitelmien mukaisesti ole tullut aktiivista menneisyyden tutkijaa, vaan historian taidot ovat olleet opetuksessa yhtenä tavoitteena sisältötiedon oppimisen sekä aktiivisen kansalaisuuden rinnalla. Artikkelissamme esitetyn oppimisprojektin kannalta oli keskeistä luoda aito tutkimusprosessi, jolle varattiin riittävästi aikaa. Tehtävään käytetty aika sekä tehtävän kompleksisuus myös mahdollistivat törmäämisen historiantutkimusprosessissa kohdattaviin kompleksisiin, historiatiedon prosessointitaitoja - kontekstualisointia, tulkintaa ja aineistojen yhdistämistä - vaativiin ongelmiin ja haasteisiin. Jos taitojen oppiminen asetettaisiin historianopetuksessa opiskelun primääriksi tavoitteeksi, tulisi opetuksen lähtökohtana olla todelliset tutkimustehtävät, jotka muodostaisivat koko opiskelun perustan. Samalla perusopetuksen painoarvo lukio-opiskelun pohjana korostuisi. Lukio ei enää toistaisi samaa mitä peruskoulussa tehdään, vaan painottamalla historiallisen tiedon ymmärtämistä ja analysointia jatkaisi ja syventäisi siitä, mihin perusopetuksessa päädyttiin.

\section{Kirjallisuus}

Ahonen, Sirkka 2014. Historia - konfliktintekijä vai sovittaja? Kosmopolis 44 (1), 59-74. Ahonen, Sirkka 2005. Essay Review. Historical consciousness: a viable paradigm for history education? Journal of Curriculum Studies 37 (6), 697-707. https://doi.org/ $10.1080 / 00220270500158681$

Bain, Robert B. 2015. Commentary: into the swampy lowlands of important problems.

Teoksessa Ercikan, Kadriye \& Seixas, Peter (toim.), New Directions in Assessing Historical Thinking. New York: Routledge, 64-72. 
Barton, David 2007. Literacy. An introduction to the ecology of written language. Malden: Blackwell.

Barton, Keith C. \& Levstik, Linda S. 2004. Teaching history for the common good. Mahwah, NJ: Erlbaum.

van Drie, Jannet \& van Boxtel, Carla 2008. Historical reasoning: towards a framework for analyzing students' reasoning about the past. Educational Psychology Review 20 (2), 87-110. https://doi.org/10.1007/s10648-007-9056-1

Duquette, Cathrine 2015. Relating historical consciousness to historical thinking through assessment. Teoksessa Ercikan, Kadriye \& Seixas, Peter (toim.), New Directions in Assessing Historical Thinking. New York: Routledge, 51-63.

Fang, Zhihui \& Coatoam, Suzanne 2013. Disciplinary Literacy: What you want to know about it. Journal of Adolescent \& Adult Literacy 56 (8), 627-632. https://doi.org/ 10.1002/JAAL. 190

Ford, Michael J. \& Forman, Ellice A. 2006. Redefining disciplinary learning in classroom context. Review of Research in Education 30, 1-31. https://doi.org/ $\underline{10.3102 / 0091732 X 030001001}$

Goldman, Susan R., Britt, M. Anne, Brown, Willard, Cribb, Gayle, George, MariAnne, Greenleaf, Cynthia, Lee, Carol D., Shanahan, Cynthia, \& Project READI 2016. Disciplinary literacies and learning to read for understanding: A conceptual framework for disciplinary literacy. Educational Psychologist 51 (2), 219-246. https://doi.org/ 10.1080/00461520.2016.1168741

Kirschner, Paul A., Sweller, John \& Clark, Richard E. 2006. Why minimal guidance during instruction does not work: An analysis of the failure of constructivist, discovery, problem-based, experimental, and inquiry-based teaching. Educational Psychologist 41 (2), 75-86. https://doi.org/10.1207/s15326985ep4102_1

Kouki, Elina \& Virta, Arja 2015. Lukiolaiset lähteillä - äidinkielen ja historian tekstitaitojen kriittistä arviointia. Teoksessa Kauppinen, Merja, Rautiainen, Matti \& Tarnanen, Mirja (toim.), Rajaton tulevaisuus - kohti kokonaisvaltaista oppimista. Jyväskylän yliopisto, 11-26.

Laine, Markus, Bamberg, Jarkko \& Jokinen, Pekka 2007. Tapaustutkimuksen käytäntö ja teoria. Teoksessa Laine, Markus, Bamberg, Jarkko \& Jokinen, Pekka (toim.), Tapaustutkimuksen taito. Helsinki: Gaudeamus, 9-38.

Lee, Peter J. 2005. Putting principles into practice: Understanding history. Teoksessa Donavan, M. Suzanne \& Bransford, John D. (toim.), How students learn: History in classroom. Washington, DC: National Academies Press, 31-77.

Lukioselvitys 2017. Kooste lukion nykytilaa ja kehittämistarpeita koskevista selvityksistä ja tutkimuksista. Opetus- ja kulttuuriministeriön julkaisuja 2017:49.

Moje, Elizabett B. 2015. Doing and teaching disciplinary literacy with adolescent learners: A social and cultural enterprise. Harvard Educational Review 85 (2), 254-279. https:// doi.org/10.17763/0017-8055.85.2.254

Monte-Sano, Chauncey 2011. Beyond reading comprehension and summary: learning to read and write in history by focusing on evidence, perspective, and interpretation. Curriculum Inquiry 41 (2), 212-249. https://doi.org/10.1111/j.1467-873X.2011.00547.x

Nokes, Jeffery D. 2013. Building Students' Historical Literacies: Learning to Read and Reason with Historical Texts and Evidence. New York, NY: Routledge. https://doi.org/ $10.4324 / 9780203137321$

Nokes, Jeffery D. 2011. Recognizing and addressing the barriers to adolescents' 'reading like historians'. The History Teacher 44 (3), 379-404. 
Nokes, Jeffery D., Dole, Janice A., \& Hacker, Douglas J. 2007. Teaching high school students to use heuristics while reading historical texts. Journal of Educational Psychology 99 (3), 492-504. https://doi.org/10.1037/0022-0663.99.3.492

Opetushallitus 2014. Perusopetuksen opetussuunnitelman perusteet 2014. Helsinki.

Opetushallitus 2015. Lukion opetussuunnitelman perusteet 2015. Nuorille tarkoitetun lukiokoulutuksen opetussuunnitelman perusteet. Helsinki.

Pedaste, Margus, Mäeots, Mario, Siiman, Leo A., de Jong, Ton, van Riesen, Siswa A. N., Kamp, Ellen T., Manoli, Constantinos C., Zacharia, Zacharias C., Tsourlidaki, Eleftheria 2015. Phases of inquiry-based learning: Definitions and the inquiry cycle. Educational Research Review 14, 47-61. https://doi.org/10.1016/j.edurev.2015.02.003

Rantala, Jukka 2012. Miten historian taitoja opetetaan? Teoksessa Ouakrim-Soivio, Najat \& Kuusela, Jorma (toim.), Historian ja yhteiskuntaopin oppimistulokset peruskoulun päättövaiheessa 2011. Koulutuksen seurantaraportit 2012: 3. Helsinki: Opetushallitus, 141-146.

Rantala, Jukka \& van den Berg, Marko 2013. Lukiolaisten historian tekstitaidot arvioitavana. Kasvatus 44 (4), 394-407.

Rantala, Jukka, Manninen, Marika \& van den Berg, Marko 2016. Stepping into other people's shoes proves to be a difficult task for high school students: assessing historical empathy through simulation exercise. Journal of Curriculum Studies 48 (3), 323-342. https://doi.org/10.1080/00220272.2015.1122092

Rantala, Jukka \& Veijola, Anna 2016. Historiallisen tiedonmuodostuksen periaatteet hukassa. Tapaustutkimus nuorten historian tekstitaidoista. Historiallinen aikakauskirja 114 (3), 267-277.

Reisman, Abby 2015. Entering the historical problem space: Whole-class, text-based discussion in history class. Teachers College Record 117 (2), 1-44.

Reisman, Abby 2012. Reading like a historian: A document-based history curriculum intervention in urban high schools. Cognition and Instruction 30 (1), 86-112. https://doi.org/ 10.1080/07370008.2011.634081

Seixas, Peter \& Ercikan, Kadriye 2015. Introduction: The new shape of history assessment. Teoksessa Ercikan, Kadriye \& Seixas, Peter (toim.), New directions in assessing historical thinking. New York: Routledge, 1-13. https://doi.org/10.4324/9781315779539

Seixas, Peter \& Peck, Carla 2004. Teaching historical thinking. Teoksessa Sears, Alan \& Wright, Ian (toim.), Challenges and Prospects for Canadian Social Studies. Vancouver: Pacific Educational Press, 109-117.

Seixas, Peter \& Morton, Tom 2013. The big six historical thinking concepts. Toronto, Canada: Nelson.

Seixas, Peter 1999. Beyond "content" and "pedagogy": In search of a way to talk about history education. Higher Education 31 (3), 317-337. $\underline{\text { https://doi.org/ }}$ 10.1080/002202799183151

Spronken-Smith, Rachel \& Walker, Rebekka 2010. Can inquiry-based learning strengthen the links between teaching and disciplinary research? Studies in Higher Education 35 (6), 723-740. https://doi.org/10.1080/03075070903315502

Thorp, Robert 2014. Towards an epistemological theory of historical consciousness. Historical Encounters 1 (1), 20-31.

Tuomi, Jouni \& Sarajärvi, Anneli 2009. Laadullinen tutkimus ja sisällönanalyysi. Helsinki: Tammi. 
VanSledright, Bruce 2010. What does it mean to think historically... and how do you teach it? Teoksessa Parker, Walter C. (toim.), Social Studies Today: Research and Practice. New York, NY: Routledge, 113-120.

VanSledright, Bruce 2002. In Search of America's Past: Learning to Read History in Elementary School. New York, NY: Teachers College Press.

Veijola, Anna 2017. Nuoret ja historian tekstitaidot: Tiedon vastaanottamisesta käsittelyyn ja käyttämiseen. Nuorisotutkimus 34 (3), 3-18.

Veijola, Anna \& Rautiainen, Matti 2018. Laukaus Kultarannassa. Kuka yritti murhata presidentti Urho Kekkosen juhannuksena 1957? Teoksessa Veijola, Anna, Rautiainen, Matti, Kupiainen, Sanni \& Mikkonen, Simo (toim.), Monilukutaidot ja tutkiva ote historian opetuksessa. Jyväskylän yliopisto, 61-79.

Virta, Arja 2002. Kohti aktiivista ja tutkivaa historian ja yhteiskuntatiedon oppimista. Lähtökohdat puntarissa. Teoksessa Löfström, Jan (toim.), Kohti tulevaa menneisyyttä. Historiallisyhteiskunnallinen kasvatus uudella vuosituhannella. Jyväskylä: PS-kustannus, 35-54.

Voet, Michiel \& De Wever Bram 2016. History teachers' conceptions of inquiry-based learning, beliefs about the nature of history, and their relation to the classroom context. Teaching and Teacher Education 55 (1), 57-67. https://doi.org/10.1016/ j.tate.2015.12.008

Voet, Michiel \& De Wever, Bram 2017. Preparing pre-service history teachers for organizing inquiry-based learning: The effects of an introductory training program. Teaching and Teacher Education 63, 206-217. https://doi.org/10.1016/j.tate.2016.12.019

Wineburg, Samuel S. 1991a. Historical problem solving: a study of the cognitive processes used in the evaluation of documentary and pictorial evidence'. Journal of Educational Psychology 83 (1), 73-87. https://doi.org/10.1037//0022-0663.83.1.73

Wineburg, Samuel S. 1991b. On the reading of historical texts: Notes on the breach between school and academy. American Educational Research Journal 28 (3), 319-346. https://doi.org/10.2307/1163146

Wineburg, Sam 2001. Historical thinking and other unnatural acts. Charting the future of teaching the past. Philadelphia: Temple University Press.

KT Anna Veijola toimii tutkijatohtorina Jyväskylän yliopiston historian ja etnologian laitoksella.

FT Sari Sulkunen toimii yliopistonlehtorina Jyväskylän yliopiston kieli- ja viestintätieteiden laitoksella.

KT Matti Rautiainen toimii lehtorina Jyväskylän yliopiston opettajankoulutuslaitoksella. 